\title{
William Blake, Selected Poems
}

\section{Emanuele Kanceff}

\section{(2) OpenEdition}

\section{Journals}

\section{Edizione digitale}

URL: http://journals.openedition.org/studifrancesi/30751

DOI: 10.4000/studifrancesi.30751

ISSN: 2427-5856

\section{Editore}

Rosenberg \& Sellier

\section{Edizione cartacea}

Data di pubblicazione: 1 avril 2006

Paginazione: 192

ISSN: 0039-2944

\section{Notizia bibliografica digitale}

Emanuele Kanceff, «William Blake, Selected Poems», Studi Francesi [Online], 148 (XLX | I) | 2006, online dal 30 novembre 2015, consultato il 18 avril 2021. URL: http://journals.openedition.org/studifrancesi/ 30751 ; DOI: https://doi.org/10.4000/studifrancesi.30751 


\section{William Blake, Selected Poems}

\section{Emanuele Kanceff}

\section{NOTIZIA}

WILLIAM BLAKE, Selected Poems. Scelta dei testi e traduzione francese di Georges BATAILLE. Versione italiana di Giuseppe UNGARETTI, a cura di Annamaria LASERRA, Torino, Giulio Einaudi Editore, 1996 («Scrittori tradotti da scrittori», 69), pp. 224.

1 Segnaliamo, pur con grande ritardo, questa bella traduzione di Bataille pubblicata anche in Italia con cura ammirevole da Annamaria Laserra, sia per gli altri testi di Bataille che l'accompagnano, sia per il folto saggio Georges Bataille lettore e traduttore di William Blake, della curatrice. 